6

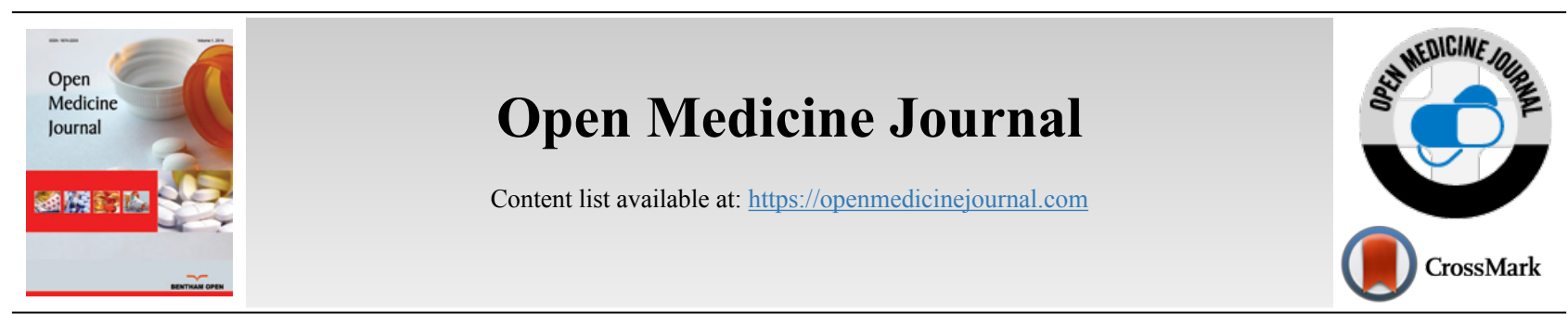

RESEARCH ARTICLE

\title{
Informed Consent for Genetics Research in Italy
}

\author{
Piergiorgio Fedeli $^{1}$, Nunzia Cannovo ${ }^{2, *}$, Rosa Guarino $^{2}$ and Vincenzo Graziano ${ }^{3}$ \\ 'Jurisprudence School, University of Camerino, Via A. D'Accorso 16, Camerino (MC), Italy \\ ${ }^{2}$ Department of Bioethics, University of Naples 'Federico II', Via Sergio Pansini 5, Naples, Italy \\ ${ }^{3}$ Department of Advanced Biomedical Sciences, University of Naples 'Federico II', Via Sergio Pansini 5, Naples, Italy
}

\begin{abstract}
:
Background:

Genetic research has become an indispensable instrument for medical research, and the subjects involved have both divergent and convergent interests.

Objective:

The possibility of having more detailed genetic information undoubtedly offers benefits for the health of the subject, but could also pose risks and make the subject vulnerable to discrimination.

The scientific community has viewed very favorably the public health utility of family history, in which data from a family whose members suffer from chronic pathologies is collected and filed, in order to develop a sort of "stratification of family risk."

Even though in the last decade the scientific and juridical literature has contributed greatly to the topic of biobanks, the perplexities that continue to surround this theme give the idea that current ethical protocols on research are inadequate.

Conclusion:

Genetic data must be used not to exploit, but to serve the person. Freedom and responsibility must be the twin guiding lights for establishing parameters for the use of biological samples. An evaluation of how this technology impacts the various aspects of the future of society is urgently needed.
\end{abstract}

Keywords: Biobanks, Genetics research, Italian normative, Informed consent, Sample, Italy.

\begin{tabular}{l|l|l|r} 
Article History & Received: October 17, 2018 & Revised: January 19, 2019 & Accepted: February 11, 2019
\end{tabular}

\section{INTRODUCTION}

The remarkable growth of knowledge in the field of genetics has meant that biological samples once considered little more than waste material are now highly prized, because the essential information they contain has become a fundamental and indispensable element for medical research, for the understanding of pathological processes, for the development of new diagnostic techniques and the creation of new therapies. In other words, this genetic information is the object of what we could define as a new "gold rush." [1].

Given the scientific value of biological samples and the development of conservation techniques, there has been a proliferation of collection centers for these samples, namely,

\footnotetext{
* Address correspondence to this author at the Department of Bioethics, University of Naples 'Federico II', Via Sergio Pansini 5, Naples, Italy; E-mail: nunzia.cannovo@gmail.com
}

"research biobanks." The term "biobanking" was first used in the scientific literature in the mid-1990s to indicate the activity of storage and conservation of biological materials (organs, tissues, blood and cells) in hospitals or other public or private organizations [2] It was used in an article on biomedical research by Steffen Loft and Henrick Enghusen Poulsen, professors of clinical pharmacology at the University of Copenhagen [3].

The phenomenon of biobanks intertwines with the theme of the human genome, which has also been addressed in terms of respect for the dignity and fundamental rights of the person in numerous international documents, which have prohibited any form of discrimination against people for reasons of their genetic patrimony (art. 11) and have limited the use of predictive genetic tests to medical or medical research purposes, with appropriate genetic consultation (art. 12) [4]. These documents have set forth the person's right to dignity 
and her/his own rights, independently of the person's genetic characteristics (art. 2) and rejected any form of discrimination based on genetic characteristics that would violate or bring about the effect of violating human rights, fundamental freedoms, and human dignity (art. 6) [5]. In particular, they have prohibited any form of discrimination based on genetic characteristics (art. 21) [6], coming out against the genetic screening of workers, except in specific cases expressly authorized by law (art. 6.12) [7], and have identified the necessary guarantees regarding genetic data, affirming the need to take into consideration and regulate the juridical status of biological samples, which could be used to constitute a source of personal information $[8,9]$.

The development of biobanks for medical-scientific research is inherently complex, involving issues such as freedom of self-determination, informed consent, protection of privacy, the sharing of genetic data, and the ownership of biological samples. law.

The present study focuses on informed consent in Italian

\section{WHAT IS A BIOBANK?}

There is no single universal definition of "biobank," but rather numerous national and international proposals united in the definition used in the scientific literature, which indicates "a structured collection of human biological material accessible on the basis of specific criteria [10, 11]" "in accordance with a code of good usage and correct behavior, and with further directions provided by Ethical Committees and Universities [12]" and "in which the information contained in the biological material can be connected to a given person [2]", "for diagnostic, therapeutic and research purposes [13]."

This definition was amplified by European Union legislation beginning in 1994 [14], which defined biobanks as "non-profit service units for the collection and storage of human biological material for genetic diagnoses, for biodiversity studies, and for research" [15]. The particular characteristic of these samples is that they can be related to the personal, genealogical and clinical data of the donors.

\section{INFORMED CONSENT FOR GENETICS-BASED MEDICAL RESEARCH}

The indispensable condition for any diagnostic or therapeutic activity concerning the genetic patrimony of a patient is the person's informed consent, in respect of the fundamental principles of human dignity and physical integrity [16]. While informed consent is central to the doctor-patient relationship in general, difficulties may arise in the specific case of genetic data, first, because a person's genetic data is shared with his or her "biological group," and second, because future research goals and uses for the sample may not have been among the purposes for which the consent was granted when the samples were taken [9]

This situation calls for careful reflection on the Italian legislation covering this phenomenon. Can the traditional concept of informed consent be applied in this context? Or must the principles involved be adapted to these new conditions?
The principle of informed consent [17] constitutes the manifestation of the freedom of self determination of the subject in relation to his/her own health and is grounded in the Constitution (articles 2, 13, 32 Const [18 - 24].). The importance of this principle is also seen in some articles of the Medical Deontology Code [25], which view informed consent as a requisite for the lawfulness and legitimacy of every diagnostic or treatment procedure. Consent must be personal, specific, expressed, aware, informed, free, and revocable at any time.

The theme of "informed consent" thus constitutes the true crux of the problem [26] in regulating research biobanks, because it concerns the relationship between the person and the parts separated from the body. In this context, there are two different phases for informed consent [27]. The first regards the removal of biological material during diagnostic or treatment procedures, and the second concerns the subject's manifestation of his/her wishes is a free act of selfdetermination regarding acts related to his/her health. Instead, with the separation of the material from the body, since the indissoluble bond between the person and biological material is lacking [28], the expression of the subject's wishes regards the protection of his/her privacy, inasmuch as the samples contain information about his/her genetic data.

More specifically, there are three fundamental moments [29] in which it is important to obtain consent:

[a] When the subject receives information and chooses to donate his or her own biological material to the physician;

[b] When the data are shared with other healthcare professionals (when the sample and information are added to the biobank);

[c] When the data obtained is made known (disclosure) and further sharing of this information with others is planned (for example, external researchers).

\subsection{Different Types of Informed Consent}

Currently, the informed consent models [30, 31] range from quite restricted models of specific informed consent [32], at one end of the spectrum, to the renunciation of all rights (Open consent [33]) at the other end. In between, there are partially narrow consent, multi-layered consent, a nonrestricted broad consent [34 - 36] and blanket consent that allows any research (Table 1). An interesting development, in addition, is a trust-based participation pact guided by solidarity and reciprocity [37].

It is obvious that such a wide range between the two extremes is due to the lack of unified national and international regulations. For this reason, informed consent is the most debated issue regarding biobanks [39].

The choice of one or the other model indicates the actuation of principles to be given pre-eminence, that is, either the freedom of scientific research or protection of the right to privacy. 
Table 1. Types of informed consent (Salvaterra $e t a l^{30}[30]$, modified).

\begin{tabular}{|c|c|c|c|}
\hline $\begin{array}{c}\text { Types of informed } \\
\text { consent }\end{array}$ & Definition & Advantages & Disadvantages \\
\hline $\begin{array}{l}\text { Specific, or fully } \\
\text { restricted, } \\
\text { informed consent }\end{array}$ & $\begin{array}{c}\text { This is the classic type of consent, in } \\
\text { conformity with bioethics } \\
\text { declarations, recommendations and } \\
\text { codes }\end{array}$ & $\begin{array}{l}\text { Biological samples and data can only be } \\
\text { used for immediate research. This model } \\
\text { guarantees the maximum protection of the } \\
\text { donor's autonomy. }\end{array}$ & $\begin{array}{l}\text { Prohibits research not authorized in the } \\
\text { original consent. High costs of research. } \\
\text { Possible loss of unused biological material. }\end{array}$ \\
\hline $\begin{array}{l}\text { Partially narrow } \\
\text { consent }\end{array}$ & $\begin{array}{l}\text { A less rigid version of specific } \\
\text { informed consent }\end{array}$ & $\begin{array}{l}\text { Allows use of the biological samples and } \\
\text { data for the immediate research and also for } \\
\text { future studies directly or indirectly } \\
\text { connected to it. }\end{array}$ & $\begin{array}{l}\text { Narrowness - not too rigid- limited to the } \\
\text { research goals stated }\end{array}$ \\
\hline $\begin{array}{l}\text { Multi-layered } \\
\text { consent }\end{array}$ & $\begin{array}{l}\text { The typical type used in studies } \\
\text { presented in the scientific literature. }\end{array}$ & $\begin{array}{l}\text { Includes different options stating the } \\
\text { knowledge goals to be reached through } \\
\text { distinct but not yet specified studies. The } \\
\text { donor can be asked to approve the use of } \\
\text { samples for: } \\
\text { 1)future studies of the same phase; } \\
\text { 2) studies in research areas that are similar } \\
\text { in terms of the pathology type (for example, } \\
\text { diabetes, cancer, etc.); } \\
\text { 3) future studies in independent research } \\
\text { areas but on the same pathology (ex. } \\
\text { pharmacokinetics studies, population } \\
\text { studies, etc.) }\end{array}$ & $\begin{array}{l}\text { When the biological material is stored in a } \\
\text { network of biobanks that manage studies } \\
\text { with totally different goals [38], it may } \\
\text { happen that the consent given is for a kind of } \\
\text { research that is totally different from kind of } \\
\text { study that researchers wish to do [38] }\end{array}$ \\
\hline Broad consent & $\begin{array}{l}\text { The consent is not actually informed. } \\
\text { Rather, it is a generic transposition } \\
\text { of news, in consideration of the } \\
\text { uncertainty of future research. }\end{array}$ & $\begin{array}{l}\text { Permits the use of biological samples and } \\
\text { their data for the research in question and } \\
\text { also for the future study of any kind. }\end{array}$ & $\begin{array}{l}\text { The rights of the subject are sacrificed to the } \\
\text { interests of the study, contrary to the national } \\
\text { and international legislation on the self- } \\
\text { determination of subjects. }\end{array}$ \\
\hline Blanket consent & $\begin{array}{c}\text { The biological sample obtained for } \\
\text { clinical tests is stored in the biobank } \\
\text { and remains there for an indefinite } \\
\text { time. }\end{array}$ & $\begin{array}{l}\text { Goals and research are not specified. The } \\
\text { donor can refuse permission for the sample } \\
\text { and data to be kept in the biobank. }\end{array}$ & \\
\hline Open consent & $\begin{array}{c}\text { This type is used for the collection of } \\
\text { biological material in populations }\end{array}$ & $\begin{array}{l}\text { No limitations to the type of research } \\
\text { allowed. }\end{array}$ & $\begin{array}{l}\text { At the moment of donation, the donors give } \\
\text { up their rights to the protection of their } \\
\text { personal data and are aware that their } \\
\text { privacy cannot be guaranteed. }\end{array}$ \\
\hline
\end{tabular}

Consequently, in regulatory systems less focused on guarantees, veracity becomes the cardinal principle that precedes the rights of the individual [29] and this pre-eminence for the right to privacy is justified by the duty of the person to participate in biomedical research, a duty grounded in the principle of solidarity [40].

This issue of informed consent must be faced with the utmost seriousness, given its implications in professional liability [41].

The European Institute of Oncology in Milan has proposed a new consent model, the result of cooperation among bioethicists, researchers, clinicians and participants, based on a "Participation Pact" [27] between researchers and donors. It focuses on trust and outlines a new form of participation in research that differs significantly from previous models, which attempted to impose on participants a "duty to participate in research." Instead, the Participation Pact is based on a relationship and offers a choice based on the principle of solidarity and reciprocity.

In this Pact, the concept of "important information" must be reevaluated, because it is not based on the information concerning the specific study (which has been traditionally interpreted as full disclosure of information concerning the potential risks and benefits of the specific experimentation for the specific participant), but on a communication of "values".

In particular, it has been suggested [42] "that: i) the concept of reciprocity should be broadened to include not only the participant and the researcher but also society as a whole; ii) the alliance between researcher, participant and society should restore the concept of trust" [43].

Based on the principle of reciprocity, researchers, participants and society as a whole, in their role as moral agents, possess both duties and rights, thus creating a network of alliances.

\subsection{Italian Legislation}

In the attempt to understand the phenomenon in the Italian juridical panorama, where there is a legislative void, one must necessarily refer to those few regulations that do exist.

The National Committee for Bioethics, the Italian government's consulting body, set forth the model of partially narrow consent [43] as the modality that permits the use of biological material for the goals of specific research that prompted the collection, and for future goals "connected" to it.

In addition, in the case of genetic biobanks, informed consent at the moment of collection must be extended to conservation and possible future use, for diagnostic purposes 
and/or those of research. Concerning this aspect, even if the European Convention of Oviedo (transposed into Italian law with L. 145/01) does not refer explicitly to biobanks, it established the lawfulness of using conserved samples as long as adequate information was provided, anonymity is guaranteed, and written consent has been given.

Two observations can be made about current Italian legislation on this subject [44], (or the lack thereof). First, the laws are specific rather than general. They regulate particular kinds of biobanks, such as those for umbilical cord stem cells $[45,46]$ or service units for security purposes [47]. Second, they only cover the treatment of personal and genetic data.

The one real instrument of reference is the Authorization for treatment of genetic data [48] issued by the Authority for the protection of genetic data [49], the independent authority to whom Italian lawmakers delegated responsibility for introducing a systematic set of rules on the subject into Italian law. It is the only important and legally binding source on the subject. However, formally it is concerned only with the treatment of genetic data, not the organic material from which the data was derived, nor is it responsible for the regulation of biobanks in general. As a result, these issues are addressed indirectly, sporadically, tangentially and fragmentally.

The one real instrument of reference is the previously described Authorisation for the treatment of genetic data [31, $49,50]$ by the Authority for the protection of personal data, which demands previous written consent from the patient for the treatment of genetic data and use of biological samples (art. 6 ), and requires that the consent regard "adequately specified" purposes. The subject need not be contacted again for consent (art. 8) if the research is directly connected with the originally authorized research, or does not diverge from it, limited to the pursuit of scientific and statistical goals directly related with the original ones [51].

Instead, for new inquiries, the subject must be contacted again in order to obtain informed consent for the treatment of personal data and the use of biological samples, unless, for particular reasons, this activity cannot be carried out, even though every reasonable effort has been made to reach the subject, and the research program, which has received approval by the ethics committee for the area, has been explicitly authorised by the Authority (in line with art.90 of the DLgs 196/03) [52].

In addition, consent given by donors is freely revocable at any moment; this involves the destruction of the biological sample, unless from the beginning it cannot be connected to an identified or identifiable person.

This authorization seems to give a concrete form to the model of "broad consent" seen as a "flexible middle way" between open and specific consent, which foresees the possibility of using biological samples for research connected to that for which the consent was given, together with guarantees for the donor, among them anonymisation of the sample, the possibility for the subject to withdraw the act of authorization for the use of samples, in any moment, and evaluation conducted by an ethics committee [53].
However, the Authorisation is restrictive in the use of data and biological samples from subjects who are incapable of providing their own consent, when the goals of the scientific research do not bring any direct benefit to the subject. More specifically, the study may be conducted exclusively if its objective is the improvement of the health of other people belonging to the same age group, or who suffer the same pathology, or who find themselves in the same conditions, and the research program has received approval from the appropriate ethics committee in the area.

In general, the Authorisation demands that free and revocable consent be given in writing before the procedure. In addition, the information sheet must detail all the goals of the research and the results that can be obtained, also in relation to unexpected information that could be learned through the effect of the treatment of genetic data. It must state the right of the subject to refuse permission for the treatment of genetic data for legitimate reasons, and specify whether or not the subject can limit the extent of communication of genetic data and the transfer of biological samples, as well as limit possible future use of these sample for other goals, unless the data and biological samples, originally or after treatment, no longer permit identification of the subject. The information sheet must explain the measures adopted to enable identification of the subject only for the time necessary for the goals of the collection or subsequent treatment [(art. 11, point 1, letter e) of the Code)], and spell out the ways the subjects who so desire can access the information contained in the research program. Finally, it must specify the period of time that the genetic data and biological samples will be conserved.

When the research is based on genetic tests, including screening, at the moment of providing informed consent, the subject must be asked whether he or she wants to know the results of the test or research, including possible unexpected findings that concern him or her, when they represent a concrete and direct benefit in terms of treatment or prevention or awareness about reproductive choices.

In addition to demanding the donor's informed consent to the collection of the sample, and consent regarding the destination of the sample, in 2008 the Authority underlined that the consent to treatment of personal data for biomedical research purposes has autonomy. It also indicated the parameters for judging the adequacy of the information to be provided to the subject in the guidelines for the treatment of personal data, in the context of clinical experimentation of medicines [54].

In the case of the death of the subject, Recommendation 4/06 of the Council of Europe [55] indicates that the use of the biological material is possible in cases when the donor did not explicitly withhold permission.

This Recommendation encourages reasonable efforts to recontact those concerned. Should there be some impediment, the Recommendation indicates that the case should be evaluated by a third party organization, which in the case of Italy is the Authority (art. 110 of D.Lgs 196/3). 


\subsection{Informed Consent for Population Studies}

Up to this point we have analysed aspects of informed consent for the patient, but we must not forget that research projects can involve an entire subgroup of a population [56], and thus consideration should be given to the repercussions not only on the individual but also on the subgroup.

The Authorisation of 2016 established that in the case of research conducted on isolated populations, any research results that have an important bearing on prevention or treatment for the community must be communicated to them and to the local authorities.

Genetic data must not be shared or published, except in an aggregated form in which it is impossible to identify the subjects, even through indirect identifying data.

In addition, before beginning a study, researchers must conduct an information campaign to inform the communities involved, and may use local mass media and public presentations to illustrate the nature and goals of the research, the methods to be used, the sources of funding, and the risks and benefits expected for the populations involved.

This information effort must also indicate the possible risks of discrimination or stigmatization of the community involved, as well as the risks of the revelation of unexpected blood ties, and the actions planned to reduce these risks as much as possible.

\section{CONCLUSION}

The lack of Italian legislation to regulate the establishment and operations of biobanks causes considerable disorientation for legal experts and operators, with no definition of this topic or the rules to be applied.

Certainly, technological discoveries have opened surprising vistas and enabled new possibilities for treatment; at the same time they have posed the delicate and unresolved challenge of achieving a fair balance between scientific advances and the protection of human rights, particularly the respect of human dignity.

The status of Italian law on biobanks is particularly fragmented, "stratified, chaotic, and characterized by heteronomy [57]." There are documents that lack legally binding content, acts of soft law (for example, the Authorization of the Authority, amply discussed above) written ad hoc and with a case by case, and not always organized, approach to regulate the essential aspects linked to treatment of data and genetic tissues by biological banks [58], deontological codes, selfregulation guidelines adopted by the individual biobanks within their network, as well as recommendations and opinions by national institutions.

Thus biobanks today are still waiting for a specific and harmonized legislative regulation also about informed consent.

In light of these considerations, it is to be hoped that lawmakers will act to define an informed consent model for participation in genetic research that facilitates scientific research while respecting the privacy of the subject's genetic data. It seems that the path to this legislative harmonization has reached a dead end. One possible outlet might be the adoption of the "broad consent" model, which allows the use of biological samples for research related to that for which consent was given, united with guarantees for the donor, such as the anonymization of the sample and an evaluation by an ethics committee [59]. Finally, biobanks should be set up as 'public entities' that are autonomous and independent of donors and researchers, in such a way that the distribution of biological samples takes place in a democratic and transparent way, with full respect for the fundamental good of the human person [60]. In this way, as augured by the National Committee for Bioethics [61], research biobanks should become a "new instrument for social solidarity."

\section{ETHICS APPROVAL AND CONSENT TO PARTI- CIPATE}

Not applicable.

\section{HUMAN AND ANIMAL RIGHTS}

No animals/ humans were used for the studies that are basis of this research.

\section{CONSENT FOR PUBLICATION}

Not applicable.

\section{CONFLICT OF INTEREST}

The authors declare no conflict of interest, financial or otherwise.

\section{ACKNOWLEDGEMENTS}

All individuals listed as authors have contributed substantially to the design, performance, analysis, or reporting of the work. and are required to indicate their specific contribution. Nunzia Cannovo and Rosa Guarino have contributed in drafting, Piergiorgio Fedeli has wrote the article, Vincenzo Graziano has contribuited in revising the manuscript.

\section{REFERENCES}

[1] Nelkin D, Marzano M, Parisoli L. Il mercato del corpo Il commercio dei tessuti umani nell'era biotecnologica, Milano, Giuffrè 2002; 5 .

[2] Loft S, Poulsen HE. Cancer risk and oxidative DNA damage in man J Mol Med (Berl) 1996; 74(6): 297-312.

[http://dx.doi.org/10.1007/BF00207507] [PMID: 8862511]

[3] Romeo Malanda S. Biobancos Enciclopedia de Bioderechoy Bioética, Catedra de Derecho y Genoma Humano, en prensa Available from: http://enciclopedia-bioderecho.com/voces/28

[4] Council of Europe. Convention for the Protection of Human Rights and Dignity of the Human Being with regard to the Application of Biology and Medicine: Convention on Human Rights and Biomedicine. 1997 April 4; Available from: http:// www.coe.int /en/ web/ conventions/ full-list/ -/ conventions/ rms/ $090000168007 \mathrm{cf} 98$

[5] UNESCO. Universal Declaration on the Human Genome and Human Rights. Available from: http:// portal.unesco.org/ en/ ev.php-

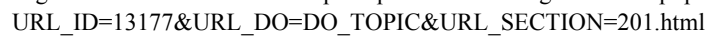
1997 November 11

[6] Charter of Fundamental Rights of the European Union. Available from: http://www.europarl.europa.eu/charter/pdf/text_en.pdf 2000 December 18;

[7] The Code of Practice of the International Labour Organisation on the protection of workers' personal data. Available from: http://www.ilo.org/global/publications/ilo-bookstore/order-online/book s/WCMS_PUBL_9221103293_EN/lang--en/index.htm 1996.

[8] Group for the protection of personal data. Working document on genetic data. Available from: https:// www.privacy.it/ 
grupridoc200403173.html 2004 March 17;

[9] Bin P, Conti A, Capasso E, et al. Genetic Risk in Insurance Field, Open Med (Wars) 2018 Aug 24; 13: 294-7.

[10] Gruppo di lavoro per la tutela dei dati personali, Documento di lavoro sui dati genetici, 17. Available from: https:// www.privacy.it/ grupridoc200403173.html 2004

[11] Conti A, Delbon P, Paternoster P, Ricci G. I test genetici Etica, deontologia, responsabilità. Milano: Giuffrè 2007; p. 103.

[12] Stelma FF. Regulations European Biobank Maastricht, Dept Epidemiolog, Maastricht University, Jan 2003.

[13] Migliori G. Biobanche: legislazione e gestione. Laboratorio 2010; 2000(February): 22-6.

[14] Reccomendation R. R(94)1 of the Committee of Ministers to member states on human tissue banks. Council of Europe. Available from: www.europa.eu 1994 March 14;

[15] Società Italiana di genetica umana e Fondazione TELETHON, Biobanche Genetiche. Linee Guida. Genova. Available from http://C:/Users/Utente/Downloads/Analysis5-6.2003.pdf 2003 July 4;

[16] PALAZZANI L. Le biobanche come problema per il biodiritto. Iustitia 2006; 31 .

[17] Frati P, Montanari Vergallo G, Di Luca M, Natale N. Gli effetti del consenso informato nella prospettiva civilistica. Riv it med leg 2002; 1041 .

[18] D'Avack L. Sul consenso informato all'atto medico. Dir fam e pers 2008; 759.

[19] Pilia A. La tutela contrattuale della personalità nel trattamento medico. Resp civ e prev 2008; 6 .

[20] Introna A. Consenso informato o rifiuto ragionato? L'informazione deve essere dettagliata o sommaria? 1998; Riv it med leg 825.

[21] Ferrando $\mathrm{S}$. Il consenso informato del paziente e responsabilità del medico, principi, problemi e linee di tendenza 1998; Riv crit dir priv 37.

[22] Barni M. L'informazione del paziente. Splendore e decadenza di un dovere medico. Medicina (B Aires) 1997; 127.

[23] Salvatore B. Informazione e consenso nella relazione terapeutica Naples: Edizioni ESI 2012.

[24] Zatti P. Dal consenso alla regola: il giurista in bioetica. Riv crit dir priv 1994; 523.

[25] Federazione Nazionale Ordini Medici Chirurgici e Odontoiatrici. Medical Deontology Code Available from: www.omceo.me.it/ ordine/ cod_deo/ commentario.pdf 2014.

[26] Bin P, Conti A, Capasso E, et al. Genetic testing: ethical aspects. Open Med (Wars) 2018; 13: 247-52.

[http://dx.doi.org/10.1515/med-2018-0038] [PMID: 29992188]

[27] Macilotti M. Consenso informato e biobanche di ricerca. La nuova Giurisprudenza civile commentata 2009; (25): 3 .

[28] Marzocco V. Il consenso informato alla conservazione e all'utilizzo di materiale biologico umano. Persona e corpo tra relazione interrotta e nuovi scenari rappresentativi.La disciplina delle biobanche a fini terapeutici e di ricerca. Trento: Forum Biodiritto 2012; pp. 151-62.

[29] Lunshof JE, Chadwick R, Vorhaus DB, Church GM. From genetic privacy to open consent. Nat Rev Genet 2008; 9(5): 406-11. [http://dx.doi.org/10.1038/nrg2360] [PMID: 18379574]

[30] Salvaterra E, Lecchi L, Giovanelli S, et al. Banking together. A unified model of informed consent for biobanking. EMBO Rep 2008; 9(4): 307-13.

[http://dx.doi.org/10.1038/embor.2008.41] [PMID: 18379580]

[31] Greenfield D, Greenberg V. Miami children's hospital: Unjust enrichment and the patenting of human genetic material, annals of health law. Available from: https:// pdfs.semanticscholar.org/ eaba/ b1c648439e514c7ecee56213861 ea5a78b06.pdf

[32] Mc Guire A, Beskow LM. Informed consent in genomics and genetic research. Annual rewiew of genomics and human genetics 2010 Sep 22; 11: 361-81.

[33] Lunshof JE, Chadwick R, Vorhaus DB, Church GM. From genetic privacy to open consent. Nat Rev Genet 2008; 9(5): 406-11. [http://dx.doi.org/10.1038/nrg2360] [PMID: 18379574]

[34] Boggio A, Adorno NB, Bernice E, Mauron A, Capron AM. Comparing Guidelines on Biobanks: emerging consensus and unresolved controversies. Geneva, Switzerland: Réseau Universitaire International de Géneve 2005.

[35] Otlowski M. Developing an appropriate consent model for biobanks: in defense of broad consent.Principles and practice in biobank governance. Burlington, VT: Ashgate Publishing Company 2009; pp. 79-92.

[36] Helgesson G. In defense of broad consent. Camb Q Healthe Ethics 2012; 21(1): 40-50.
[http://dx.doi.org/10.1017/S096318011100048X] [PMID: 22152457]

[37] Sanchini V, Bonizzi G, Disalvatore D, et al. A trust-based pact in research biobanks. From theory to practice. Bioethics 2016; 30(4): 260-71.

[http://dx.doi.org/10.1111/bioe.12184] [PMID: 26307361]

[38] German National Ethic Council, Nationaler Ethikrat, Biobanks for research, Berlin, 2004. Disponibile Ondine. http:// www.ethikrat.org/ english/ press/2004_03.html 2010 november 4;

[39] Cambon-Thomsen A. The social and ethical issues of post-genomic human biobanks. Nat Rev Genet 2004; 5(11): 866-73. [http://dx.doi.org/10.1038/nrg1473] [PMID: 15520796]

[40] Santosuosso A. Should privacy be abolished in biobanking? Proceeding of the Conference on Comparative Issues in the Governance of Research Biobanks. 2010, May 7-8; Trento.

[41] Bin P, Conti A, Capasso E, et al. Genetic Testing and Professional Responsibility: The Italian Experience. Open Med (Wars) 2018; 13 : 298-300.

[http://dx.doi.org/10.1515/med-2018-0046] [PMID: 30155520]

[42] Sanchini V, Bonizzi G, Monturano M, et al. Research Biobanks: Why Information And Information-Based Consents Are Not Enough. Bioethics 2016; 30: 260-71.

[http://dx.doi.org/10.1111/bioe.12184] [PMID: 26307361]

[43] Comitato Nazionale per la Bioetica (CNB) and Comitato Nazionale per la Biosicurezza, le Biotecnologie e le Scienze della Vita (CNBBSV).. Raccolta di campioni biologici a fini di ricerca: consenso informato. 2009. Available from: http:// presidenza.governo.it/ biotecnologie/ documenti/ Comunicato_consenso_informato.pdf

[44] Penasa S. Verso un sistema normativo integrato: il caso delle biobanche di ricerca.Forum Biodiritto. 2012; p. 328.

[45] Ordinanza del Ministro della Salute, 4 Maggio 2007, n 110, Misure urgenti in materia di cellule staminali da cordone ombelicale Official Gazzette n 1102007 May 14;

[46] Marini L. Le biobanche di cellule staminali cordonali tra norme comunitarie e disciplina nazionale In: Dir comm internaz. 2007; p. 893.

[47] 2009.Legge 30 giugno 2009, n 85 Adesione della Repubblica italiana al Trattato di Prum Official Gazzette 13 luglio 2009, n 160

[48] Privacy Authority. Autorizzazione n 8/2016 - Autorizzazione generale al trattamento dei dati genetic 2016 December 15 Official Gazzette n 303, 2016 December 29

[49] dlgs $n 196,2003$ June 30 Codice in materia di protezione dei dati personaliOfficial Gazette n 1742003 July 29;

[50] Comitato Nazionale per la Biosicurezza e le Biotecnologie. Linee guida per la certificazione delle biobanche Available from: Available from:

http://presidenza.governo.it/biotecnologie/documenti/7 biobanche 1.p df 2006.

[51] Macilotti M, Izzo U, Pascuzzi G, Barbareschi M. La disciplina giuridica delle biobanche. Pathologica 2008; 100: 86-101.

[PMID: 18792524]

[52] Lattanzi R. Ricerca genetica e protezione dei dati personali.Trattato di biodiritto Ambito e fonti del biodiritto. Milano: Giuffrè Editore 2010.

[53] European Commission. Recommendation 25 on the ethical, legal and social implications of genetic testing. Brussels Available from: https://publications.europa.eu/en/publication-detail/-/publication/53d8 4d00-5153-498e-9492-47f1 fcae5d27 2004.

[54] Authority for the treatment of personal data. Guidelines for the treatment of personal data in clinical experimentation of medicines, 24 July 2008. Official Gazzette 2008, n 190, August 14

[55] Council of Europe. Recommendation Rec (2006)4 of the Committee of Ministers to member states on research on biological materials of human origin Available from: http://www.coe.int/ 2006.

[56] Austin MA, Harding S, McElroy C. Genebanks: a comparison of eight proposed international genetic databases. Community Genet 2003; 6(1): $37-45$. [PMID: 12748437]

[57] Lorenzon S. La regolamentazione delle biobanche all'incrocio tra diritto dell'Unione e discrezionalità legislativa nazionale: alla ricerca di un punto di equilibrio tra riservatezza e libertà di ricerca scientifica, in La disciplina delle biobanche a fini terapeutici e di ricerca. In: Casato C, Piciocchi C, Veronesi P, Eds. La disciplina delle biobanche ai fini terapeutici $\mathrm{e}$ di ricerca Available from: http://eprints.biblio.unitn.it/3979/1/casonato_piciocchi_veronesi_quad erno_101_versione_corretta_giov19apr2012.pdf

[58] Bin R. Soft law, no law.Soft law e hard law nelle società postmoderne. 2009.

[59] European Commission. Raccomandazione n. 20. In: 25 
Recommendations on Ethical, legal and social implications on genetic testing Bruxelles. 2004.

[60] Articolo BA. 2 della Costituzione.Commentario della Costituzione, I principi fondamentali Bologna. 1975; p. 101.

61] Comitato Nazionale di Bioetica. Raccolta di campioni a fini di ricerca:consenso informato. Available from: www.governo.it 2009 February 16

\section{2019 Fedeli et al.}

This is an open access article distributed under the terms of the Creative Commons Attribution 4.0 International Public License (CC-BY 4.0), a copy of which is available at: (https://creativecommons.org/licenses/by/4.0/legalcode). This license permits unrestricted use, distribution, and reproduction in any medium, provided the original author and source are credited. 